Astraea, Vol. 1 , No 2,2020

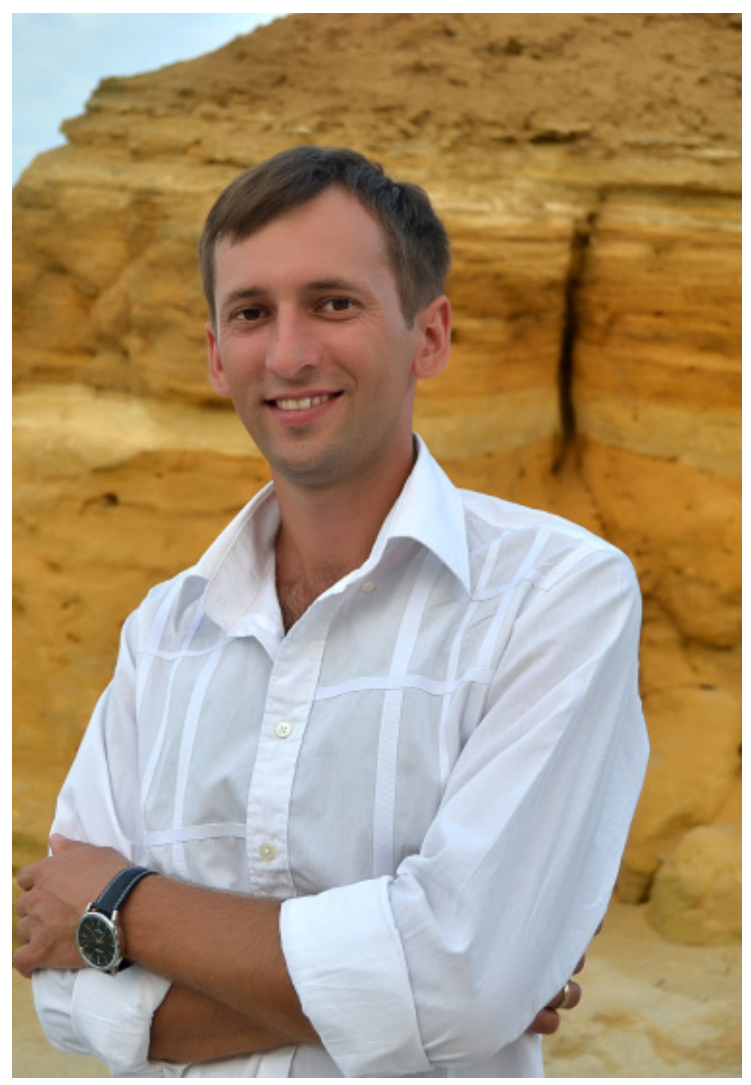

POETRY

\title{
ABOUT THE AUTHOR \\ YAROSLAV SKIDAN
}

doi: 10.34142/astraea.2020.1.2.09

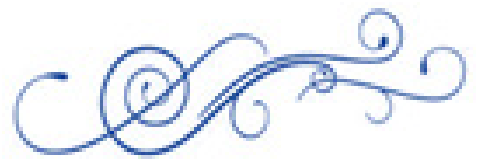

SKIDAN Yaroslav

E-mail: yaskidan@ukr.net

«The old clock was slowly counting hours and minutes. In spite of the fact that the morning rays tickled his nose and prevented him from concentrating, the shaggy boy about 9 years old was drawing something on an unevenly torn off sheet of paper, then was crossing it out, then was writing again. Giving birth to the word, thoughts mixed with feelings fluttered in his shaggy head. This made him to reach for the pen and write again. Victories and failures, joys and sorrows, unknown depths of existence, a magical kaleidoscope of nature and, first of all, love - all this excited and inspired, added up in a moment and settled in verse lines, sealing up in the word. The pointers of a clock ran forward and counted the years. Uneven sheets of paper were folded into books», - said Yaroslav Skidan about his becoming.

Skidan Yaroslav - modern Kharkiv poet, member of the National Union of Writers of Ukraine, teacher of Ukrainian language and literature, head head of the circle «Literary Creation» at the municipal institution «Kharkiv center of research and experimental activities «Teachers House» of the Kharkiv regional council, graduate student of the Ukrainian language department of Kharkiv National Pedagogical University named after H.S. Skovoroda. Yaroslav Skidan started writing in the childhood, at the age of nine. He is an author of poetry collections «Tomorrow 
will be...» (2007), «At the crossroads» (2011), books for children. Expect for artistic creative work Yaroslav Skidan is also known as a translator (he translated books for children from Byelorussian) and he does scientific research in the department of philology, in particular, ukrainian linguistics. The poet's poems are distinguished by a high artistic level, patriotic direction and current understanding of eternal themes. Yaroslav Skidan - diplomat and winner of nationwide Ukrainian literary festivals, participant of nationwide Ukrainian conference of young men of letters, multiple winner of regional literary seminar-review «Young Slobozhanshchina», winner of International Literary and Artistic Prize of M. Syngaivskii.

This is how the modern Ukrainian poet was born: « «The boy gradually became a member of the National Union of Writers of Ukraine. But Thoughts and Feelings didn 't leave him and therefore the Words continue to live and ask permission to be on paper». I suggest you seeing some of them.

Svitlana Kryvoruchko Doctor of Sciences (Philology), Professor, Head of the Department of Foreign Literature and Slavic Languages, H.S. Skovoroda Kharkiv National Pedagogical University (Ukraine)

$* * *$

Kharkiv autumn,

A long scarf on her shoulders, leaves in her red hair, about to welcome the evening is Mrs. Kharkiv autumn 
The sun dancing in her eyes,

the fountains are breaking into a dance

and, as if besotted by that are kissing her legs.

Autumn is laughing at that

and continues her walk in the park

- Why is the heart so happy?

- Kharkiv evening is upon us!..

\title{
English translation Svitlana Perlova literary redaction by Tatyana Varenko
}

\author{
$* * *$ \\ It is raining, in a rush cracking the sky open \\ as if wanting to shower generous gifts. \\ A spectator today, I do not need to hurry,
} lost amid drops, I am waiting: for the Maitre to compose a tenderly winged melody - of a flock of doves flying. The sky has become beautiful despite all the weeping. May work be humming alongin and deadlines approaching What is mine will be - mine, and it won `t escape me. The rain came and went leaving its traces on the asphalt. I have been in stand by 


\section{Skidan Yaroslav, Svitlana Kryvoruchko}

sticky fussing around just not for me

Trucks are rattling along; trees are playing

Vivaldi everyone wait. I have waited for calm for so long...

$* * *$

The sun has buried

its beams in clay

with a bit of its soul

left within the ground.

God found that clay

and created a human,

but retained one piece

hidden in His hands.

He gave it to the human

to use it to invent

sounds and words

for speaking.

And for as long as

the language exists,

for so long will

the human race live.

English translation by Koval Kateryna

literary redaction by Tatyana Varenko 


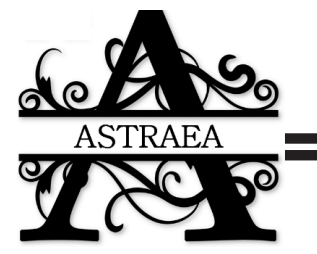

Received: 15.07 .2020

Accepted: 15.08 .2020

\section{Cite materials as:}

Skidan, Y., Kryvoruchko, S. (2020). About the author Yaroslav Skidan. Poetry. Kharkiv autumn, It is raining in a rush cracking the sky open, The sun has buried. Astraea, 1(2), 137-141. doi: 10.34142/astraea.2020.1.2.09

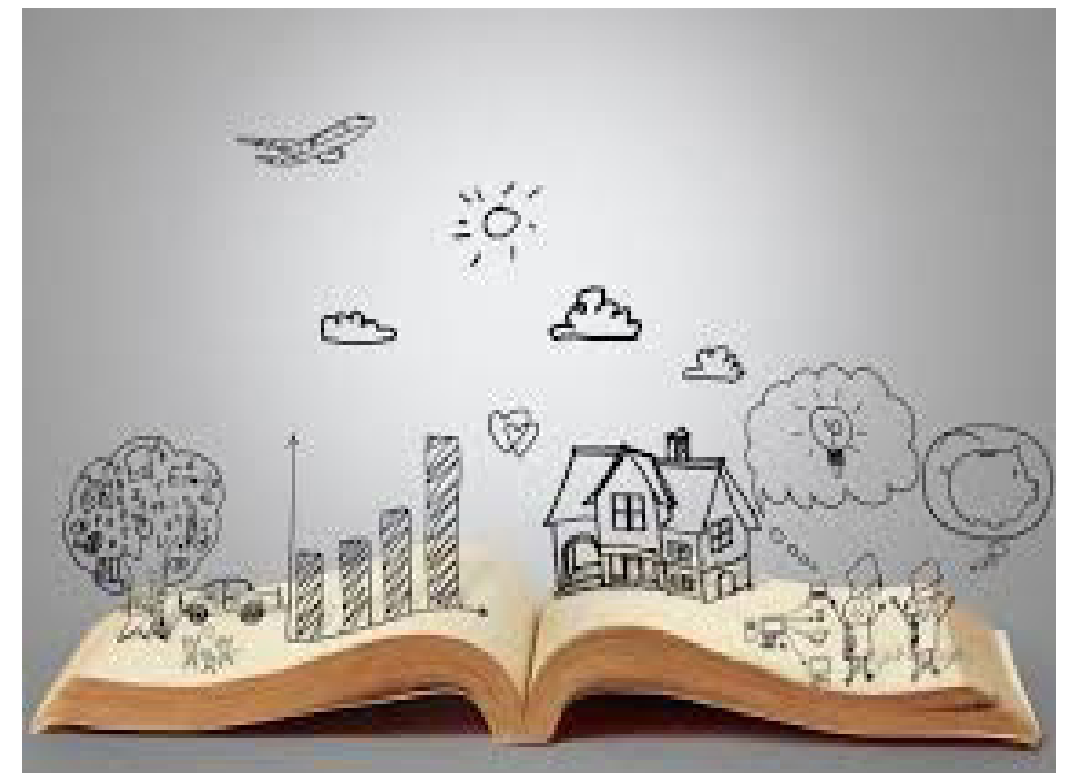

